\title{
From Shell Shock to Shellac: The Great War, Blindness, and Britain's Talking Book Library
}

\begin{abstract}
Britain's Talking Book Service began as a way of providing reading material to soldiers blinded during the First World War. This account traces the talking book's development from the initial experiments after the War to its debut and reception among blind soldiers and civilians in the 1930s. It has been put together using archives held by the Royal National Institute of Blind People (before its Royal Charter, the NIB) and Blind Veterans UK (formerly St. Dunstan's), the two organizations responsible for Britain's Talking Book Service. The essay's first section reconstructs the search for an alternative way of reading that would benefit people with vision impairments. The next part demonstrates the talking book's impact on the lives of people with disabilities, recovering the voices of blind readers left out of most histories of books, literacy, and reading practices in the twentieth century. The final section reconstructs a debate over the value of recorded books, showing that disputes over their legitimacy are as old as recorded books themselves. In sum, this essay confronts the central issue raised by the convergence of books, media, and disability in the War's aftermath: can a book talk?
\end{abstract}

The Royal National Institute of Blind People (RNIB) celebrated the fiftieth anniversary of the Talking Book Service in 1985. The organization's pioneering efforts to record books on specially modified gramophone records for a small group of blind and partially sighted individuals had grown into a professional operation that reached nearly

\footnotetext{
*m.rubery@qmul.ac.uk. The research for this article was generously supported by a grant from the Leverhulme Trust. The author would like to thank Patricia Meyer Spacks, Chris Hilliard, and Vanessa Warne for comments on earlier versions of this essay. Thanks are also due to the RNIB (especially Philip Jeffs, Robert Saggers, and Sarah Haylett), Blind Veterans UK (especially Robert Baker), and the British Library (especially Jonathan Summers).
} 
half of an estimated 130,000 blind people in Britain. ${ }^{1}$ After starting out with fifty-five books in 1935, the library held nearly 6,000 titles. ${ }^{2}$ Its Golden Jubilee was marked by a visit from the Prime Minister, Margaret Thatcher, who had listened to talking books while recovering from eye surgery, and a commemorative ceremony in recognition of the Service's 60,000th member. ${ }^{3}$

Reverend Robert Manthorp, Headmaster of Worcester College for the Blind, honoured its achievements by recalling how attitudes towards blindness had changed since the program began: 'Fifty years ago blind persons . . were, in truth, thought of as being "not quite nice"; there was something wrong with them, they offended the taste of respectable people and therefore were hidden away behind high walls'. The general attitude, he went on to say, was that 'blindness is something rather nasty, let's keep away'. ${ }^{4}$ The Talking Book Service marked a turning point by recognizing the shared interests, capabilities, and humanity of people with visual disabilities. Manthorp credited those who refused to accept that people with disabilities were somehow different from other people-those who, in Manthorp's words, 'refused to believe a man was stupid because he was blind'. ${ }^{5}$

The British public's interest in blind welfare was hardly a new phenomenon, however. Sighted people had shown interest in blind literacy since at least the late eighteenth century. ${ }^{6}$ Inaccessibility to books was a particular concern among philanthropists, educated people, and religious leaders who worried that blind people would not have access to the Bible. Subsequent generations were equally fascinated by blind people's acquisition of literacy through the spread of tactile reading methods and the opening of schools for blind pupils throughout the nineteenth century. ${ }^{7}$ The London Society for Teaching the Blind to Read was established in 1838, for example, and the

1 The figure is cited in Andrew Timothy, 'Introduction', typescript, September 16, 1985, Folder 'Talking Books-50th Anniversary' (uncatalogued), Royal National Institute of Blind People. Hereafter cited as RNIB. The RNIB's archive was located in Stockport at the time of my consultation. It was moved to London in October 2012.

${ }^{2}$ Lucille Hall to David Tytler, July 23, 1985, Folder 'Talking Books-50th Anniversary' (uncatalogued), RNIB.

3 "Prime Minister Marks 50th Anniversary of Talking Books," June 21, 1985, Folder 'Talking Books-50th Anniversary' (uncatalogued), RNIB.

${ }^{4}$ Untitled typescript, September 17, 1985, Folder 'Talking Books-50th Anniversary' (uncatalogued), RNIB.

${ }^{5}$ Untitled typescript, September 17, 1985, Folder 'Talking Books-50th Anniversary' (uncatalogued), RNIB. Deborah Cohen examines changing attitudes toward mental disability in Family Secrets: Shame and Privacy in Modern Britain (Oxford, 2013), 87-123.

${ }^{6}$ On attitudes towards blind literacy, see Robert Heller, 'Educating the Blind in the Age of Enlightenment: Growing Points of a Social Service', Medical History, 23.4 (1979), 392-403.

7 For historical accounts of the resources available to people with vision impairments in Britain, see Gordon Phillips, The Blind in British Society: Charity, State, and Community, c. 1780-1930 (Aldershot, Burlington, Vermont, 2004) and John Oliphant, The Early Education 
National Library Service for the Blind was set up in 1882. The Talking Book Service arose from the public's understanding of the needs of blind people as well as broader cultural shifts related to education, literacy, and disability rights activism.

Advocacy groups had long sought accessible reading formats for people with vision impairments by the time sound-recording technology made it possible to record a full-length book on a set of gramophone records. One publication described 'the inability to read' as the greatest handicap imposed by blindness. ${ }^{8}$ Embossed books allowed some people to overcome this hardship. ${ }^{9}$ But raised type offered no help to people who could not read Braille. They depended instead on volunteers to read aloud to them. Their plight received public attention after the return of soldiers who had lost their eyesight during the First World War (whose number continued to grow as the delayed effects of mustard gas and other chemicals became apparent). ${ }^{10}$ These men could not read without other people's help. War-blinded veterans represented a challenge and an imperative to develop an alternative means of reading for those who could not read for themselves.

The War was a catalyst for the reconceptualization of blind veterans and civilians alike. ${ }^{11}$ Blinded servicemen returning from the War gave a degree of urgency to problems of literacy that had long been tolerated. Before the War, blindness had been regrettable and unfortunate, but it was not a problem for which the public bore any direct responsibility. The War changed all that. The British public owed a debt to the disabled ex-servicemen who had sacrificed their eyesight defending the country. In the absence of state compensation, disabled veterans relied

of the Blind in Britain c. 1790-1900: Institutional Experience in England and Scotland (Lampeter, 2007).

8 Ian Fraser, 'The Talking Book', St. Dunstan's Review for Blinded British Soldiers, Sailors and Airmen, 20.212 (1935), 2-3; 2.

9 On tactile reading in Britain, see John Oliphant, "Touching the Light": The Invention of Literacy for the Blind', Paedagogica Historica, 44.1 (2008), 67-82; Mary Wilson Carpenter, Health, Medicine, and Society in Victorian England (Santa Barbara, 2010), 128-48; and Vanessa Warne, "'So That the Sense of Touch May Supply the Want of Sight": Blind Reading and Nineteenth-Century British Print Culture', in Colette Colligan and Margaret Linley, eds., Media, Technology, and Literature in the Nineteenth Century: Image, Sound, Touch (Aldershot, 2011), 43-64.

${ }^{10}$ Causes of blindness during the War are listed in Arnold Lawson, War Blindness at St. Dunstan's (London, 1922).

11 On attitudes towards disabled veterans, see Seth Koven, 'Remembering and Dismemberment: Crippled Children, Wounded Soldiers, and the Great War in Great Britain', American Historical Review, 99.4 (1994), 1167-202; Joanna Bourke, Dismembering the Male: Men's Bodies, Britain and the Great War (London, 1996), 31-75; Jeffrey S. Reznick, Healing the Nation: Soldiers and the Culture of Caregiving in Britain during the Great War (Manchester, 2004); Ana Carden-Coyne, Reconstructing the Body: Classicism, Modernism and the First World War (Oxford, 2009), and Julie Anderson, War, Disability and Rehabilitation in Britain: "Soul of a Nation" (Manchester, 2011). 


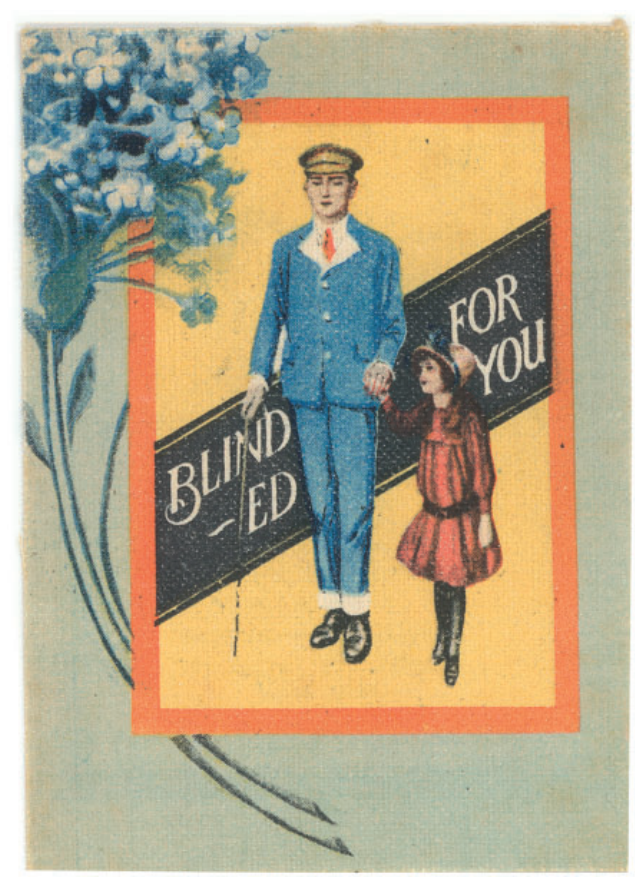

Figure 1

Image of a blind soldier used in fund-raising campaigns by St. Dunstan's. Courtesy of Blind Veterans UK.

on voluntary and philanthropic organizations for treatment and rehabilitation. ${ }^{12}$ Campaigns to raise funds on behalf of veterans appealed directly to the public's conscience through the prominent display of the wounded soldier's body. For example, St. Dunstan's charity for the rehabilitation of blinded ex-servicemen featured a disabled veteran alongside the caption 'BLINDED FOR YOU' (Fig. 1). ${ }^{13}$ Such campaigns reminded the public of its obligation to make the lives of disabled veterans tolerable by supplying them with entertainment including books. Veterans who were unable to read Braille, however, required an alternative to print.

The story of the talking book in Britain has yet to be told. ${ }^{14}$ This account traces the talking book's development from the initial

12 On the postwar care of disabled veterans, see Deborah Cohen, The War Come Home: Disabled Veterans in Britain and Germany, 1914-1939 (Berkeley, 2001).

13 Tony Allen lists uses of this phrase for fund-raising campaigns in St Dunstan's and the Great War (York, 1999).

14 The only history of the RNIB's Talking Book Service is the brief account in Mary G. Thomas, The Royal National Institute for the Blind 1868-1956 (Brighton, 1957), 66-9. The 
experiments after the First World War to its debut and reception among blind soldiers and civilians in the mid-1930s. It has been put together using archives held by the RNIB (before its Royal Charter, the NIB) and Blind Veterans UK (formerly St. Dunstan's), the two organizations responsible for Britain's Talking Book Service. The first part reconstructs the search for an alternative way of reading that would benefit people with vision impairments. The primary goal here is recovery work: to put together an account of the talking book's origins in Britain to stand alongside those written in the USA. ${ }^{15}$ The next part demonstrates its impact on the lives of people with disabilities. It documents how the first generation of readers, many who had given up hope of ever reading again, responded to talking books. This section recovers the voices of blind readers left out of most histories of books, literacy, and reading practices in the twentieth century. ${ }^{16}$ The final section attends to the format's critics by reconstructing a debate over the value of recorded books. As we will see, prejudicial attitudes towards blind people were not the only obstacles to progress. The talking book met equally strong opposition from blind readers. Disputes over the legitimacy of recorded books are as old as recorded books themselves.

This essay confronts the central issue raised by the convergence of books, media, and disability in the War's aftermath: can a book talk? The term 'talking book' derives from a bibliographic vocabulary even though it remains an open question whether the talking book is a book at all. My account establishes a precise affiliation between the two media, arguing that the talking book evolved in relation to the printed one while at the same time calling into question what reading meant to people during the interwar years in Britain. ${ }^{17}$ The fraught nature of this relationship is evident in reluctance to use the term 'reading' to describe the act of listening to books. Many accounts use 'reading' within quotation marks or neologisms such as 'reader-listeners' or 'listener-readers'. These formulations reflect a degree of uncertainty over the exact nature of the relationship between reading and hearing a

RNIB website features the timeline History of Talking Books: Our Progress and Achievements <http://www.rnib.org.uk/livingwithsightloss/reading/news/Pages/readon13_tbanniversary2.aspx> accessed 5 November 2012 and Robert Kirkwood's radio program '75 Years of Talking Books' (2010) <https://itunes.apple.com/gb/podcast/talking-books/id768727141?mt=2> accessed 5 November 2012.

15 Accounts of the talking book in the USA include Frances A. Koestler, The Unseen Minority: A Social History of Blindness in the United States (New York, 1976), That All May Read: Library Service for Blind and Visually Handicapped People (Washington, DC, 1983), and Marilyn Lundell Majeska, Talking Books: Pioneering and Beyond (Washington, DC, 1988).

16 See, for example, Joseph McAleer, Popular Reading and Publishing in Britain 1914-1950 (Oxford, 1992) and Robert James, Popular Culture and Working-Class Taste in Britain, 19301939: A Round of Cheap Diversions? (Manchester, 2010).

17 See D.L. LeMahieu's account of the gramophone, cinema, newspaper, and other forms of mass entertainment to influence aesthetic traditions in A Culture for Democracy: Mass Communication and the Cultivated Mind in Britain between the Wars (Oxford, 1998). 
book. They arise from an unresolved set of questions about reading: Is reading inherently visual or can we apprehend books through other sensory organs including the ears and fingers? How does the speaker's voice affect the process of interpretation? What effect does the machine's presence have on a book's reception? Does it matter if a book cannot be touched? We should not expect pioneers of the Talking Book Service to be able to answer such questions since they remain unanswered to this day. But questions about aesthetic preferences were beside the point for most blind readers in the 1930s. For them, talking books meant the difference between reading and not reading at all.

\section{The Dream of a Talking Book Library}

Books have never been of much use to people who cannot see. The history of blind literacy is one of attempts to adapt the printed book into alternative formats as soon as technology made it possible to do so. Dreams of a mechanical reading device had preoccupied auditors ever since Thomas Edison's invention of the phonograph in 1877. The gramophone represented a potential prosthesis for blind people by allowing them to read books through another person's eyes. ${ }^{18}$ Captain Ian Fraser first conceived of a talking book while listening to a gramophone at St. Dunstan's: 'It ought to be possible, I thought, to record human speech. Theoretically it should be possible to record whole books ${ }^{\prime 19}$ Fraser joined St. Dunstan's after being shot through the eyes by a German sniper at the Battle of the Somme in July 1916; he went on to become the organization's Chairman at the age of 24 years. Once there, he began experimenting with a Dictaphone, a device used to record speech onto wax cylinders. ${ }^{20}$ Working with a recording engineer in a makeshift studio at St. Dunstan's, Fraser recited scraps of poetry and speeches for subsequent trials. According to his autobiography, 'These were really the first talking-book records, and were the first beginnings of the Talking Book'.21

Physical disabilities generate new forms of media. ${ }^{22} \mathrm{New}$ forms of sound-recording technology such as the long-playing (LP) record

18 James Lastra discusses the capacity of nineteenth-century media to extend human faculties in Sound Technology and the American Cinema: Perception, Representation, Modernity (New York, 2000), 6.

19 Ian Fraser, My Story of St. Dunstan's (London, 1961), 106. See also David Castleton, Blind Man's Vision: The Story of St Dunstan's in Words and Pictures (London, 1990).

20 'Talking Books for the Blind' (14 March 1938), 1-5; 3, Folder 'Demonstrations and Talks on Talking Book Machines' (uncatalogued), RNIB.

${ }^{21}$ Ian Fraser, Whereas I Was Blind (London, 1942), 100.

${ }^{22}$ Friedrich A. Kittler attributes the origins of media to 'Physiological deficiency', in Michael Metteer, with Chris Cullens, trans., Discourse Networks 1800/1900 (Palo Alto, 1990), 231. 


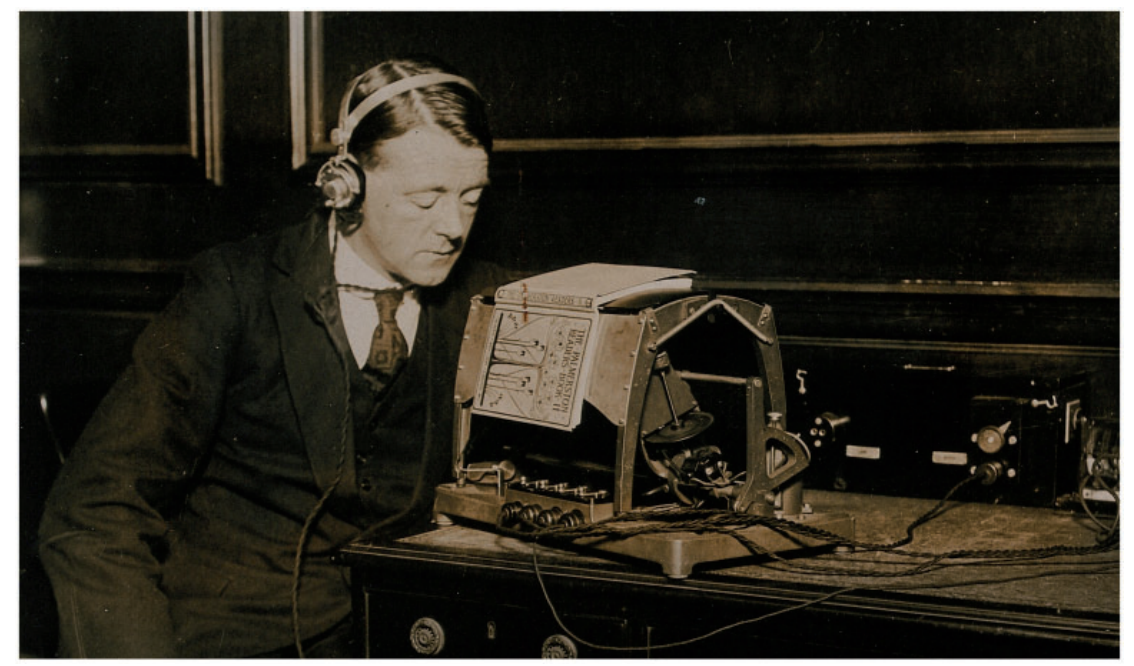

Figure 2

A blind man reading a book using the Optophone. Wellcome Library, London.

presented an opportunity to remake the book for the ears instead of the eyes. Still, veterans had to wait more than a decade after the War for a technological alternative to reading aloud. Before the 1930s, records were unsuitable for books since they could only play for a few minutes; the LP record was not ready for the commercial market until $1948 .^{23}$ Blind people benefitted from the technology much earlier, however, when the NIB and St. Dunstan's, working with record labels such as the Gramophone Company (later HMV), succeeded in making discs capable of playing at the reduced speed of 24 revolutions per minute (rpm) for up to 25 minutes per side.

The gramophone was chosen on the basis of economic viability rather than technical superiority. Proposed alternatives to the talking book had even indicated that it might not be necessary to record speech at all. Headlines from the 1920s such as 'Ear Books for the Blind' gave the impression that the next breakthrough in blind literacy would be the musical book, not a talking one. The headline referred to the Typophone, which played a sound alphabet derived from Morse code on a phonograph record. ${ }^{24}$ Similarly, the Optophone transformed letterpress into musical notes (Fig. 2). Additional experiments were

${ }^{23}$ Peter Martland, Recording History: The British Record Industry, 1888-1931 (Lanham, Maryland, 2013).

${ }^{24}$ Raymond Francis Yates, 'Ear Books for the Blind: A Great Invention that Makes It Possible to Produce an Entire Book on a Single Phonographic Record', Popular Science Monthly, 98.5 (1921), 24. 
made with tactile reading machines, including the Visagraph and Photoelectrograph, which made a magnified, embossed copy of any printed page. $^{25}$ In addition, the Technical Research Committee's preference for 'speaking films' over phonograph records reflects abiding concerns about the risk of investing in a medium that might soon be obsolete. ${ }^{26}$ All of these devices were rejected, however, as too impracticable or expensive for the average blind person.

In the spring of 1934, the NIB and St. Dunstan's announced their intention to launch the Talking Book Service. The NIB's Technical Research Committee (with whom Fraser had worked for the past decade) had brought the talking book within the bounds of possibility, thanks to technological advances, such as electrical recording, in the gramophone, radio, and film industries. ${ }^{27}$ Talking books could at last be made at a reasonable cost. Fraser had also learned that the American Foundation for the Blind had begun its own talking book program. As he told readers of the St. Dunstan's Review, 'I do not want to excite undue hopes, but I think that in the near future it may be possible to establish a Library of Talking Books' ${ }^{28}$

The Talking Book Library had no way of knowing in advance how appealing the format would be to a blind readership, many of whom had been accustomed to printed books before losing their sight. Bibliographic terms such as 'library' and 'books' continued to associate the new technology with the familiar and reassuring realm of print. The NIB established the Sound Recording Committee in May 1934 to develop, manufacture, and distribute the machines and records. ${ }^{29}$ The Library began at a rudimentary studio in Regent's Park. The studio was described by Fraser as 'a hut in my own garden, which I used to use as a workshop'. ${ }^{30}$ There, Anthony McDonald recorded the first talking book in Britain. ${ }^{31}$

25 The NIB's Technical Officer, Edward J. Pyke, describes the equipment tested in 'Sound-Recording for the Blind: A History of Experiment', The New Beacon: A Magazine Devoted to the Interests of the Blind (February 1936), 37-8 and 'Sound-Recording for the Blind: A History of Experiment', New Beacon (March 1936), 67-8. See also Franklin S. Cooper, Jane H. Gaitenby, and Patrick W. Nye, 'Evolution of Reading Machines for the Blind: Haskin Laboratories' Research as a Case History', Journal of Rehabilitation Research and Development, 21.1 (1984), 51-87.

26 'Excerpts of the Technical Research Committee Minutes Dealing with Sound Recording', typescript, n.d., p. 1, File CRO/119, Folder T55/51A, RNIB.

27 On the use of electrical recording from the 1920s, see David L. Morton, Jr., Sound Recording: The Life Story of a Technology (Westport, CT, 2004).

28 Ian Fraser, 'Talking Books', St. Dunstan's Review (1934), 2.

29 Minutes, Sound Recording Sub-Committee, 8 May 1934, 1, Folder 'Sound Recording Committee 1934-1960' (uncatalogued), RNIB.

30 Ian Fraser, 'Chairman's Notes', St. Dunstan's Review, 647 (1973), 2-3; 2.

31 Anthony McDonald is credited as the first narrator in Ian Fraser, 'Chairman's Notes',

St. Dunstan's Review, 647 (1973), 2-3; 2. 


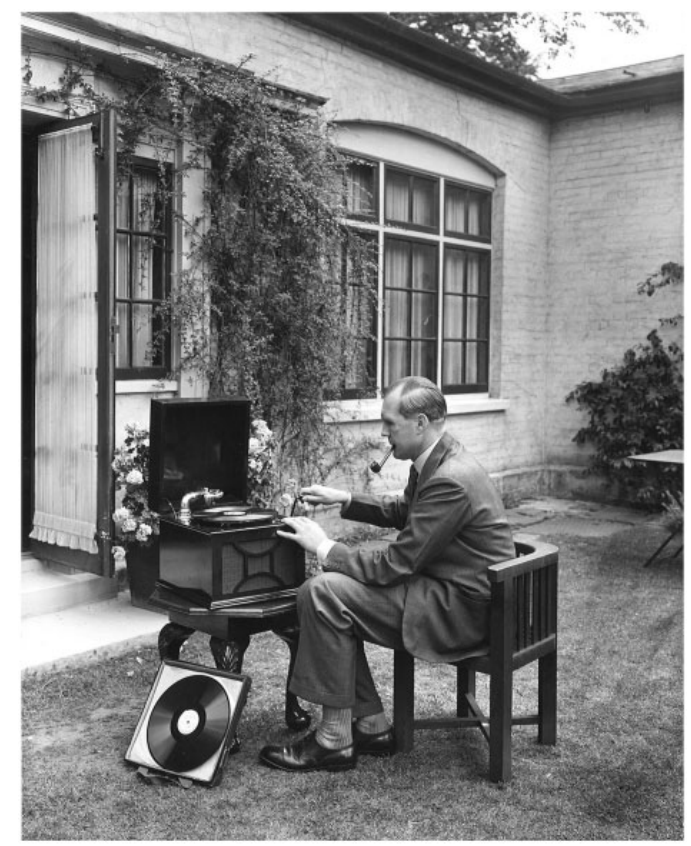

Figure 3

Ian Fraser listening to a talking book. Courtesy of Blind Veterans UK.

The Talking Book Library began a 2-year trial period on 1 August 1935. Membership was restricted to those registered as blind and 'any others who can give satisfactory evidence of their inability to read ordinary books'.32 The Talking Book Library hardly resembled other libraries. Its books required custom-made machinery in order to be read, and talking books cost more to manufacture than printed books. Funding was scarce since the service received no public subsidy. Whereas the United States Library of Congress's talking book service received funding from the government, the NIB and St. Dunstan's relied entirely on private donations from Lord Nuffield, the Carnegie United Kingdom Trust, and the Pilgrim Trust, familiar sources of cultural philanthropy in the interwar period that sought to improve the lives of people with disabilities or to help people reach their cultural potential. ${ }^{33}$ They were among the many philanthropic organizations

32 Minutes, Sound Recording Sub-Committee, October 9, 1935, 1-6; 5, BVUK. A formal set of rules ('Talking Book Library for the Blind: Rules') was included in the appendix to a report on the meeting between the Sound Recording Committee and the AFB, 13 August 1934, BVUK.

${ }^{33}$ The most substantial support came from Lord Nuffield, who, after a preliminary gift of $£ 5,000$ in 1936 , went on to provide a total of $£ 37,500$ in the program's first decade. The 
that helped rehabilitate wounded veterans in the absence of state support. ${ }^{34}$

Talking books went out to readers on 7 November 1935, nearly 1 year after the distribution of similar records in the USA. They were considerably larger than their print counterparts. Each title consisted of a set of 12-inch shellac gramophone discs that could play for approximately 25 minutes per side; the average book took up ten double-sided records, which were shipped at no cost to borrowers, who had only to pay the return postage (Fig. 3). ${ }^{35}$ Membership was free to anyone who purchased (or received through charity) one of three different models of talking book machines: an electric gramophone; a mechanical model requiring no electricity; and a model designed for use with either headphones or a radio loudspeaker. Machines were sold at cost price, ranging from $£ 6.10$ s. to $£ 3.15$ s.4d. St. Dunstan's subsidized $£ 1$ of each machine purchased by veterans. ${ }^{36}$ By the end of September 1937, talking book machines had been delivered to 338St. Dunstaners, 351 blind civilians, and 275 recipients abroad. ${ }^{37}$

The Library's catalogue adhered closely to the public taste for printed books. The first talking books were Agatha Christie's The Murder of Roger Ackroyd, Joseph Conrad's Typhoon, and The Gospel According to St. John. ${ }^{38}$ As a spokesperson recalled, 'The Talking Book Library started to circulate books on November 7th, 1935 with the smallest library, I should think, in the world-to wit, three titles' ${ }^{39}$ Axel Munthe's The Story of San Michele and William Gore's There's Death in the Churchyard were also among the earliest recordings. Titles were chosen for their broad appeal and resembled those in other popular fiction series begun the same year; Agatha Christie, for example, was among the first authors in the Penguin paperbacks series too. ${ }^{40}$ Little thought was given to their relevance to a blind readership with the exception of The Story of San Michele, described as 'a modern masterpiece that has a particular interest for all blind people' owing to its author's blindness. ${ }^{41}$ Outside sponsorship also influenced the

Carnegie United Kingdom Trust granted an additional $£ 500$ per annum for 3 years towards research.

${ }^{34}$ On compensation for disabled veterans, see Cohen, 15-60.

35 The Post Office Amendment Act of 1936 extended Braille postage rates to talking book packages.

36 'IV. Talking Books', NIB Annual Report 1936-1937 (London, 1937), 21-23; 23.

37 'Report on Talking Book Developments February 1936-September 1937', typescript, 24 September 1937, File CRO/203, Folder T55/9, RNIB.

38 Minutes, Sound Recording Sub-Committee, 24 July 1935, BVUK. I have been unable to locate any documents confirming whether the first recording was Christie or Conrad. 39 'Talking Books for the Blind', 3.

40 Alistair McCleery, 'The Paperback Evolution: Tauchnitz, Albatross and Penguin', in Nicole Matthews and Nickianne Moody, eds., Judging a Book by its Covers: Fans, Publishers, Designers, and the Marketing of Fiction (Aldershot, 2007), 3-17.

${ }^{41}$ 'Talking Books for the Blind', 3. 
selection. The Gospel According to St. John was the first part of the Bible recorded because the British and Foreign Bible Society offered to pay for it. $^{42}$

The Talking Book Selection Committee was entrusted with the difficult decisions over which titles to include in the catalogue. Its policy called for at least 75 per cent of the titles to be of permanent value. ${ }^{43}$ According to one observer, 'the discriminating, but sometimes too austere taste of the classicist, has been tempered with consideration for those weaker brethren who prefer "a good murder" to Elizabethan verse' ${ }^{44}$ The Library's modest budget made the selection process highly contentious. The Committee considered suggestions made by members and correspondents, lists of classics, and the bestsellers from the past 3 years. At the end of the Library's first year, it held fifty-five complete works (twenty-four recorded in Britain, thirty-one in America). ${ }^{45}$ Recipients were nearly unanimous in their enthusiasm for the recordings, though many complained about the limited inventory.

\section{A Revolution in the Blind World}

Fraser wrote to thank Lord Nuffield, the Talking Book Library's most generous benefactor, after the first books went out to readers: 'You in turn after Louis Braille have created a revolution in the blind world by starting the TALKING BOOK LIBRARY FOR THE BLIND, and the benefit of this development in the happiness and future usefulness of a blind community which is more alert, more in touch with things, more capable of self-expression and enjoyment of life, is beyond estimation' ${ }^{46}$ It was a revolution in both senses of the word: an upheaval in the way people read and on what they read. Fraser insisted that the talking book represented a second revolution in blind literacy, pointing to the three quarters of the blind community who had lost their sight in adult life and, as a consequence, could not read Braille. ${ }^{47}$ He said of this constituency, 'These people are not only cut off from the pleasures of books, but reading means more to them than to others who have so

\footnotetext{
42 Minutes, Sound Recording Sub-Committee, 17 February 1937, Folder 'Sound Recording Committee 1934-1960' (uncatalogued), RNIB.

43 Minutes, Talking Books Selection Sub-Committee, 25 April 1935, BVUK.

44 'The Talking Book Arrives', New Beacon, 19.224 (1935), 201-4; 202.

45 The initial titles recorded in Britain are listed in Minutes, Talking Books Selection Sub-Committee, 25 April 1935, BVUK. There is a pencil tick next to the four titles that had already been recorded. The list is reprinted in 'The Talking Book Arrives', New Beacon, 19.224 (1935), 201-4; 202 and 'Report of the Year's Work', NIB Annual Report 1935-36 (London, 1936), 9-19; 18.

46 Ian Fraser to Lord Nuffield, 22 July 1936, BVUK.

47 For example, see Fraser's comments in 'Remarks by Lord Fraser of Lonsdale', in Milton D. Graham, ed., Science and Blindness: Retrospective and Prospective (New York, 1972), 174-7.
} 
many alternative occupations' ${ }^{48}$ This is a plea for what might be called 'blind exceptionalism', the notion that blind readers thought of themselves as a group with distinctive needs, capabilities, and desires that set them apart from other readers.

The best way to measure how blind readers thought of themselves in relation to books is through their own words. Correspondence received by the NIB and St. Dunstan's allows us to gauge the talking book's reception, from public demonstrations across the country to private sessions in people's homes. Despite scant evidence of reader responses-a problem faced by all historians of reading and an especially acute one when dealing with a medium that lacks marginalia - a representative sample has been retrieved from archives. The NIB published extracts from its correspondence with talking book recipients, for example, and Fraser received nearly 100 letters after the first machines went out. ${ }^{49}$ If the available evidence does not confirm whether reading meant more to blind people than to other people, as Fraser alleged, it nevertheless documents the impact talking books had on their lives. As we will see, readers perceived the talking book both as a restoration of the ability to read and as an altogether new way of reading.

In 1936, the NIB introduced the talking book to blind constituencies throughout the country. Demonstrators promoted the machine's benefits while simultaneously reassuring prospective users that it would not disrupt their daily routines. Presentations began with a sales pitch: 'The prospect of being able to sit back in a comfortable chair and hear the best, or the worst, literature of the world read to you by a man with a golden voice is extraordinarily attractive ${ }^{\prime 50}$ Demonstrations took place before large organizations including the Northern Counties Association for the Blind, Midland Counties Association for the Blind, and Union of Counties Associations for the Blind. Other people heard the machine at the NIB's headquarters or at reading groups. Forty people attended the readings organized by the North Wales Society for the Blind, for example, and the reading circle held at Manchester's National Library for the Blind heard all twenty-two discs of Thackeray's Henry Esmond. ${ }^{51}$

The NIB introduced the talking book in terms of the familiar practice of reading aloud. Nearly all blind readers had been read to by family, friends, volunteers, or professional readers. Yet, such recitations could

48 Ian Fraser to Lord Nuffield, 22 July 1936, BVUK.

49 Ian Fraser, 'Chairman's Notes', St. Dunstan's Review, 20.219 (1936), 1-2; 2.

50 Ernest Whitfield, 'Notes for Dr. Whitfield's Speech to the Union of Associations for the Blind, Clothworkers' Hall, Thursday, 12th March 1936', typescript, 1-4;1, File CRO/ 119 , Folder T55/51, RNIB.

51 'Progress Report', 17 December 1935, File CRO/203, Folder T55/9, RNIB; Clipping, 'Bulky Books', Manchester Evening Chronicle, 26 June 1936 (uncatalogued), RNIB. 
be difficult to arrange; many blind people were reluctant to impose on others; and professional readers were expensive. An advertisement in St. Dunstan's' Annual Report of 1934 announced: 'There are few greater pleasures for the blind than reading aloud; but wife and friends are not always available. The TALKING BOOK will supplement the human reader, ${ }^{52}$ The final line defuses anxieties about the replacement of humans by a machine. The talking book left existing arrangements intact while presenting additional opportunities for reading on demand: 'Clear, agreeable reading aloud whenever this is wanted' ${ }^{53}$ The benefits appealed even to those who had access to regular readers.

The 'mechanical "reader aloud"' sought to preserve the activity's intimacy without its awkwardness. Hence, Fraser reassured audiences that the talking book machine was equal and even superior to human speakers:

I have listened to a good many experimental records which have been made and I can assure my fellow St. Dunstaners that if you sit down quietly with a reading machine and listen to a book that interests you, you will get just as much pleasure out of it as if a really competent reader is personally at your service. Indeed, the readers of our records are very much better than most of the friends or family members of the family who have been good enough to read to me in the past, and, what is more, the machine does not get tired, does not want to stretch and look out of the window and scratch its head or poke up the fire or see about something else and, best of all, you do not have to put yourself in the position of asking someone to read to you when they may want to do something else. ${ }^{54}$

Comparisons between talking book machines and human readers served a purpose. As James Lastra has argued, personification helps people to understand and even to normalize new media. ${ }^{55}$ Any unease towards the machinery was neutralized, in this instance, by the assurance that 'a really competent reader is personally at your service'. Such comparisons made the potentially alien machinery seem as human as possible-as did human connotations of the phrase 'talking book' itself. At the same time, the NIB and St. Dunstan's emphasized the machine's superiority. Humans were unreliable, difficult to manage, and not always good readers. The voice's perfection became possible only through the gramophone's mediation, which eliminated nearly all traces of human fallibility. As one patron declared, 'these beautiful

\footnotetext{
52 'The Talking Book', Nineteenth Annual Report of St. Dunstan's for Year Ended March 31st 1934 (London, 1934), 14.

53 'The Talking Book', Nineteenth Annual Report of St. Dunstan's, 14.

54 'The Talking Book', St. Dunstan's Review (1935), 2-3; 3.

55 Lastra, Sound Technology and the American Cinema, 5-8.
} 
readers of our Talking Books are never tired, never argumentative, and never in a hurry, bless them! ${ }^{\prime 56}$ The talking book machine made audiences aware of constraints they had tolerated, wittingly or unwittingly, before its arrival. Listening to family lost its appeal once you could be read to by professional actors.

The talking book had the greatest impact on people who could not read in any other way. Testimonials from people who had lost their sight vividly illustrate the plight of those denied access to literature. Such people associated books with their former lives and, in many cases, had lost hope of ever enjoying them again. One person testified: 'I should like to state what great pleasure I derive from the Talking Book. I have been a life-long invalid, and I used to read a great deal. I also painted, and composed poetry, this latter being the only thing I was able to go on with when I became blind. What joy and interest the "Talkie" book has brought into my life! ${ }^{57}$ This invalid's diminishing sphere of interests was reinvigorated by books-a form of entertainment whose sonification was as dramatic for blind people as that of cinema (the 'talkies') for other people. ${ }^{58}$

Correspondents expressed gratitude at being able to read again. One dumbstruck reader wrote: 'Words are totally inadequate to express my gratitude for the Talking Books. How thankful I am for them and the wonderful service! ${ }^{59}$ Many attributed to divine providence the seemingly miraculous restoration of their ability to read. 'The books are a wonderful blessing', wrote a grateful reader. ${ }^{60}$ A veteran from Carshalton described them as 'an absolute God-send to us fellows'. ${ }^{61}$ Similar explanations invoked the scriptural tradition of viewing blindness in religious terms. Talking books fulfilled Isaiah's promise to turn darkness into light.

Mechanical reading devices offered what blind people most desired: independence. The talking book gave those who did not already have such freedom at their fingertips a chance to read without interference. As Deborah Cohen has shown, many people with disabilities, deprived of employment, pensions, or good health, had to endure the indignities of dependence. ${ }^{62}$ At least one reader wondered whether people with access to libraries could appreciate the change: 'Sighted readers, and also blind people who can read Braille fluently, can have little

56 Letter to the Editor, New Beacon (July 1938), 193-4; 193.

57 'IV. Talking Books', NIB Annual Report 1936-1937 (London, 1937), 23.

58 See Jeffrey Richards, The Age of the Dream Palace: Cinema and Society in 1930s Britain (London, 2010) and John Sedgewick, Popular Filmgoing in 1930s Britain: A Choice of Pleasures (Exeter, 2000).

59 'Appreciation of Talking Books', NIB Report for 1948-1949 (London, 1949), 12-13; 13.

60 'Talking Books', RNIB Report for 1952-1953 (London, 1953), 16.

61 'Points from Letters', St. Dunstan's Review, 21.223 (1936), 3.

62 Cohen, The War Come Home, 102. 
conception of what the Talking Book means to us older blind who have hitherto been entirely dependent on kind friends or paid readers to furnish our mental pabulum' ${ }^{63}$ The talking book both read to people and allowed them to read for themselves. An advertisement assured St. Dunstaners that, while the talking machine would do the actual reading, its operator was in control of everything else: 'He will work it himself at his own time in his own home'. ${ }^{64}$ Fraser was not exaggerating the discomfort felt by many blind people towards burdening family and friends. One of the first recipients of a talking book machine stated: 'It is glorious to be able to sit back and be read to, without even so much as asking the person if they mind doing it' ${ }^{\prime}{ }^{6}$ The glory owed as much to the removal of an obligation as to the reading itself.

Such enthusiasm stands out since blind people were thought to have fewer opportunities for recreation than their peers. As Helen Keller pointed out, boredom was the greatest threat. ${ }^{66}$ The talking book entertained them while also providing a break from tedious, solitary lives. One woman placed the talking book a notch below her marriage in the satisfaction (if not intimacy) it gave her: 'The Talking Book is, with the exception of my husband, the greatest joy of my life' ${ }^{67}$ Letters vividly describe the pleasure afforded by talking books. 'Oh! the joy of hearing it', wrote another reader after receiving a book in the post. 'I felt like flying over the moon with pleasure'. ${ }^{68} \mathrm{~A}$ few readers measured the talking book's impact quantitatively as well as qualitatively. In 1948, a woman claimed to have read 145 talking books-nearly a quarter of the Library's entire collection. ${ }^{69}$

Pleasure had particular connotations in the aftermath of the First World War. Blinded veterans listened to talking books for enjoyment as well as diversion from distressing memories of trench warfare in northern France. Such trauma lies behind the following letter written in 1936 by a blinded soldier from Guildford named F.G. Braithwaite:

This is how I enjoy the Talking Book.

Every night at about ten o'clock I shoot the wife off to bed, then make up the fire, draw my armchair near, and, after having got a bottle of Worthington and a cigarette going, I switch on the Talking Book.

63 Letter to the Editor, New Beacon (July 1938), 193-4; 193.

64 'The Talking Book', Nineteenth Annual Report of St Dunstan's, 14.

65 Quoted in 'The Talking Book Arrives', New Beacon, 19.224 (1935), 201-4; 203.

66 Helen Keller, 'The Heaviest Burden on the Blind', in Out of the Dark (New York, 1913), 211-18, 212.

67 'Talking Books', NIB Annual Report 1939-1940 (London, 1940), 10-12; 10.

68 'Improved Talking Book Service', RNIB Report for 1955-1956 (London, 1956), 19.

69 'Appreciation of Talking Books', NIB Report for 1948-1949 (London, 1949), 12-13; 13. 
Don't you think this is real luxury?

If the book is particularly interesting, it is possible I may have another disc and another Worthington, retiring to bed about midnight, taking care to replace disc in box and empties in proper place.

I have only read two books and thoroughly enjoyed each. Not being able to sleep much, and being very poor at Braille, you can imagine how useful the Talking Book is to me. ${ }^{70}$

The letter might be from any man until the final lines reveal it to be the testimony of a soldier who has struggled to learn Braille after losing his eyesight in the War. From shell shock to shellac: the talking book stands alongside alcohol and cigarettes as the soldier's nightly sedative. ${ }^{71}$ The machine enabled blind soldiers to read for themselves at a time when many disabled veterans were unable to participate in domestic life. Here, the soldier asserts his masculinity through the enjoyment of beer, smoking, and the comforts of marriage denied to many disabled servicemen. ${ }^{72}$ The veteran, despite his injuries, was still able to recreate the comforts of home in the war's aftermath.

The talking book offered solitary entertainment and even a private space for the reader's reflections. A retired teacher listed it as one of three diversions he enjoyed in solitude: 'The Talking Book, the wireless and my pipe are my only pleasures. I am an old schoolmaster and was a very great reader until I lost my sight. I no longer dread the dreary evenings of the past'. ${ }^{73}$ The British Wireless for the Blind Fund had begun supplying free radios in $1929 .{ }^{74}$ Another reader expressed relief at having a way to pass the time, writing, 'The Library is an immense compensation, largely dispelling the monotony of blindness'. ${ }^{75}$ Still

70 F.G. Braithwaite to Ian Fraser, 11 January 1936. Reprinted in Twenty-First Annual Report of St. Dunstan's for Year Ended March 31st 1936 (London, 1936), 14. Braithewaite's life is discussed in Fraser, Whereas I Was Blind, 54-55, and My Story of St. Dunstan's, 136-37.

71 The scholarship on trauma and the First World War is extensive. Histories published in the last decade include Peter Leese, Shell Shock: Traumatic Neurosis and the British Soldiers of the First World War (Basingstoke, 2002), Ben Shephard, A War of Nerves: Soldiers and Psychiatrists, 1914-1994 (London, 2002), Peter Barham, Forgotten Lunatics of the Great War (New Haven, 2004), Edgar Jones and Simon Wessely, Shell Shock to PTSD: Military Psychiatry from 1900 to the Gulf War (Hove, 2005), and Fiona Reid, Broken Men: Shell Shock, Treatment and Recovery in Britain 1914-1930 (London, 2010).

72 Bourke, Dismembering the Male: Men's Bodies, Britain and the Great War, 162-70; Cohen, The War Come Home: Disabled Veterans in Britain and Germany, 1914-1939, 105.

73 Quoted in 'Appreciation of Talking Books', NIB Report for 1948-1949 (London, 1949), $12-13 ; 13$.

${ }^{74}$ The Fund is described in W. McG. Eagar, 'Blindness in Great Britain', in Paul A. Zahl, ed., Blindness: Modern Approaches to the Unseen Environment (Princeton, 1950), 26-36, and Mark Pegg, Broadcasting and Society 1918-1939 (London, 1983), 165. On radio listening, see Paddy Scannell, A Social History of British Broadcasting. Vol. 1, 1922-1939: Serving the Nation (Oxford, 1991), 356-80. See also Rebecca Scales, 'Radio Broadcasting, Disabled Veterans, and the Politics of National Recovery in Interwar France', French Historical Studies, 31.4 (2008), 643-78. 
others looked forward to hearing books when they were housebound. T.W. Chamberlain of Hull declared, 'I am highly delighted with my machine. It will help me to pass many a dull moment away, especially in the winter time when I cannot get out ${ }^{\prime}{ }^{76}$ For many blind readers, the passing of time in real life was as important as escaping from it in an imagined one.

The talking book served social as well as aesthetic purposes. The NIB used talking books, along with the radio, to reduce the social exclusion felt by blind people. Talking books offered social interaction, or at least a simulation of it. One reader wrote to the NIB, 'Your books come as a faithful friend to visit $\mathrm{us}^{\prime}{ }^{77}$ The timeworn metaphor of reading as a form of companionship takes on additional poignancy in the context of a disabled readership with limited opportunities for social contact. The most isolated patrons understood this figure of speech literally. For this reason, the NIB described the machine's speech as 'like the voice of a friend' ${ }^{78}$ Simulated companionship was meant to renew the social ties maintained by people before losing their sight.

The NIB viewed the talking book as a way to address mental health issues. In some cases, reading about other people's lives made people value their own. A reader with multiple disabilities described how listening to talking books had renewed his interest in the outside world: 'Life becomes interesting again to a man without sight, smell or taste'. ${ }^{79}$ His response fulfilled the NIB's principal goal: not only to make life bearable (though this was important) but also to engage people with the world around them.

The problem's severity is evident in the melodramatic terms used by blind people to describe the talking book's impact. David Copperfield's famous account of 'reading as if for life' takes on greater urgency when applied to a disabled readership suffering from a range of mental health issues. ${ }^{80}$ 'It is the Talking Book that makes blindness bearable', admitted one reader. ${ }^{81}$ For him, talking books were less a way to pass the time than the very reason for doing so. Others described books in even more extreme terms. A correspondent wrote: 'My machine has at times meant the difference between life and death to $\mathrm{me}^{\prime} .{ }^{82}$ Distressed

\footnotetext{
5 Quoted in 'Talking Books', RNIB Report for 1952-1953 (London, 1953), 16.

6 Quoted in 'Points from Letters', St. Dunstan's Review, 21.223 (1936), 3.

7 Quoted in 'Talking Books', RNIB Report for 1952-1953 (London, 1953), 16.

8 'Talking Books', NIB Annual Report 1939-1940 (London, 1940), 10-11; 10.

79 'The Talking Book Library', RNIB Report for 1954-1955 (London, 1955), 17.

80 Charles Dickens, David Copperfield (London, 1996), 60.

81 'The Talking Book Library', RNIB Report for 1954-1955 (London, 1955), 17.

82 'The Latest Model of the Talking Book Machine', RNIB Report for 1956-1957 (London, 1957), 17.
} 
readers turned to talking books for solace in lives otherwise marred by ill health or bereft of social contact.

Appreciative letters also came from family. One reader described the 'comfort and joy' records had given a woman celebrating her ninetieth birthday. ${ }^{83}$ Relatives saw firsthand the talking book's impact, especially for people who had relied on volunteers to read aloud to them. A wife confided, 'I simply do not know what my husband would have done without the Talking Books' ${ }^{\prime}{ }^{84}$ Families struggled to imagine life without them. As one mother wrote, 'I should just like to say what a boon the Talking Book is to my son; I do not know what he would do without it now ${ }^{\prime} .85$ As was the case with other forms of entertainment including film and radio, a technology that initially generated unease in households quickly came to be seen as indispensable. ${ }^{86}$

Correspondence convinced Fraser, at least, of the talking book's value. Letters indicate how people felt about talking books even if only a small percentage of recipients wrote to describe their feelings towards them. Many had no way of writing to the NIB even if they had wanted to. Still, Fraser interpreted the congratulatory letters from blinded soldiers as confirmation of the Talking Book Service's value. 'Reading their remarks made me think this was one of the best things we had done', wrote Fraser. 'I think some hundreds of our men will enjoy this service for the rest of their lives' ${ }^{87}$

\section{Talking Book or Reading Book?}

The debate over the legitimacy of recorded books has a long history. This debate's modern version usually takes place between readers who have a choice between reading narrative in print or hearing it read aloud. Georgina Kleege, for one, has described skepticism towards recorded books as a prejudice among sighted people. ${ }^{88}$ But talking books have faced questions about their legitimacy ever since their debut in the 1930s. In fact, the strongest opposition came not from bibliophiles but from blind readers themselves, who were the first to raise questions about the relationship among reading, technology, and self-dependence.

The most impassioned of these debates took place in the New Beacon, a magazine founded by the NIB to supply information for teachers and

83 'Talking Books', RNIB Report for 1952-1953 (London, 1953), 16.

84 'Talking Books', RNIB Report for 1952-1953 (London, 1953), 16.

85 'IV. Talking Books', NIB Annual Report 1936-1937 (London, 1937), 23.

86 On public enthusiasm for, and anxieties towards, new technologies, see Bernhard Rieger, Technology and the Culture of Modernity in Britain and Germany, 1890-1945 (Cambridge, 2005).

87 Ian Fraser to Neville Pearson, 4 March 1936, BVUK.

88 Georgina Kleege, Sight Unseen (New Haven, 1999), 190. 
care workers supporting blind and partially sighted people. This magazine provides a valuable record of dissenting viewpoints from a readership that, owing to the nature of its disabilities, left behind few traces. Spirited attacks on and defenses of talking books preserved in its pages take us beyond the promotional rhetoric of advocacy groups to what blind readers themselves thought about the biggest development in blind literacy since Braille.

The controversy started with Arthur Copland's editorial 'TalkingBook or Reading-Book?' in the February 1937 issue. ${ }^{89}$ A graduate of the Edinburgh School for the Blind, Copland began contributing to the New Beacon after writing a prize-winning letter about the prospect of a new Braille publication. He went on to write about issues such as careers for people with vision impairments and the psychology of blindness. These pieces gave little warning of the controversy to come when Copland wrote his editorial calling into question whether the talking book was worth the expense.

'Talking-Book or Reading-Book?' acknowledged the new format's enthusiastic reception. Fraser promoted talking books as the biggest breakthrough since Braille, and the New Beacon itself heralded their importance to readers, school teachers, home visitors, and others concerned with blind welfare. ${ }^{90}$ Instead of joining the celebrations, however, Copland played the contrarian role by asking whether the publicity truly benefited the blind community. He accused the promotional campaign of 'indiscriminate propaganda' that threatened public support for Braille (p. 34). Despite the existence of tactile forms of literature for over a century, he complained, the talking book had been hailed as an 'Open Sesame' into the realm of letters (p. 33). He also raised doubts about the expenditure in time and money that could have been invested in other aspects of blind welfare.

Copland voiced prescient concerns about the risks posed by new technologies to an already endangered Braille community. ${ }^{91}$ At the same time, worries that new media threaten to replace existing media, rather than work in conjunction with them, made it difficult for Copland to recognize the talking book's potential benefits even for Braille users. ${ }^{92}$ The essay's most controversial feature was Copland's

89 Arthur Copland, 'Talking-Book or Reading-Book', New Beacon, 21.242 (1937), 33-5. Hereafter cited parenthetically by page number.

90 'The Talking Book Arrives', New Beacon, 19.224 (1935), 201-4; 201.

91 On the link between emerging technologies and declining Braille literacy, see 'Braille is Spreading but Who's Using It?', BBC News Magazine, 13 February $2012<$ http:/ /www. bbc.co.uk/news/magazine-16984742>. The article is based on the National Federation of the Blind report, 'The Braille Literacy Crisis in America', 26 March $2009<\mathrm{http}: / /$ www. $\mathrm{nfb}$.org/images/nfb/documents/pdf/braille_literacy_report_web.pdf > .

92 See the accounts of emerging communications media in David Thorburn and Henry Jenkins, eds., Rethinking Media Change: The Aesthetics of Transition (Cambridge, MA, 2003). 
portrayal of the talking book as an illegitimate form of reading. For Copland, reading to oneself was superior to being read to by someone else (or by a machine). Silent reading entailed 'self-dependence' that could not be matched by the 'artificial facility' of hearing a book read aloud (p. 34). Raised types such as Braille compelled readers to sound out words for themselves and to engage directly with the author's words. By contrast, 'Being read to, however perfectly the reading may be done, necessarily involves the intrusion of a third personality between the author and his public' (p. 34). However accurate, the allegation disregards the fact that blind people had relied on reading aloud long before the arrival of talking books. This context was left out of Copland's devaluation of talking books as a potential rival to Braille: 'The talking-book can never surpass or replace the reading-book in real utility' (p. 35). Not even the most ardent champion of talking books had proposed using them as a replacement for print.

The New Beacon's next issue wryly noted that Copland's article had aroused 'a lively expression of feeling' on the subject. ${ }^{93} \mathrm{~A}$ forum titled 'Talking Book or Reading Book? Some Opinions on the Question' reprinted extracts from the numerous letters received by the magazine's editors (p. 68). The first item challenged by respondents was the article's false opposition. W. Percy Merrick of Shepperton opened the column by declaring: 'There is room for both the Talking Book and for Braille reading and writing' (p. 68). A man from Winkleigh, North Devon raised a similar point, asking, 'Why does Mr. Copland make the Talking Book a rival of the Braille Book?' (p. 70) Others also objected to placing the two formats in needless competition. In fact, the most vocal defenses of the talking book came from readers who were fluent in Braille. C.W. Killingbeck of Chester, for one, objected to assumptions that readers could not enjoy both media. Those who read exclusively by ear, he continued, usually did so because they could not read in any other way: 'Surely the Talking Book wins because it gives literature to those who have it not' (p. 68). As correspondents pointed out, the havenots included most of the blind population.

Efforts to undermine the credibility of talking books were based on premises that infuriated the magazine's readership. Responses ranged from the incredulous ('Mr. Arthur Copland's article is quite a shock to me') to the indignant ('I consider it laughable') (p. 70, p. 71). To begin with, Copland characterized as a minority the talking book's target audience of aging people who lost their sight late in life. ${ }^{94}$ In fact, this

\footnotetext{
93 'Talking Book or Reading Book? Some Opinions on the Question', New Beacon (March 1937), 68-71; 68. Hereafter cited parenthetically by page number.

94 On aging and disability, see Pat Thane, Old Age in English History: Past Experiences, Present Issues (Oxford, 2000).
} 
group made up a majority of the blind population. Many of them had never learned to read Braille; as a correspondent pointed out, the National Library had only 11,000 registered Braille readers out of a blind population of roughly 30,000..$^{95}$ Second, Copland doubted whether the aged and infirm would be able to operate the talking book apparatus. Yet, gramophones were simple to use; those who struggled to do so would most benefit from listening to a machine operated by a third party. Third, Copland insisted that a lack of privacy would prevent many people from listening to books, though headphones were available in such cases. Finally, Braille had required years of development and government subsidy. As one of the first St. Dunstaners to receive a talking book machine had written: "If this is what they call its "infancy"-Glory! what will it be when it reaches maturity? ${ }^{96}$ The only allegation to go uncontested was Copland's assertion that the high number of blinded veterans was unlikely to happen again.

Not all readers disagreed with Copland. Several respondents concurred that talking books posed a threat to Braille. Hazel Winter, for one, worried about its impact on prospective readers. Learning a new language was difficult work at a time when people who were newly blind were most vulnerable to depression. Braille advocates feared that talking books might tempt potential finger readers to take the easier option of being read to by a machine over the arduous commitment of reading by touch. According to Winter, 'the Talking Book will be either an inducement to laziness or a mere luxury' (p. 69). She echoed Copland's concerns that the talking book would siphon resources away from other problems facing the blind community, including the need for machinery to read directly from print. Such technological innovations were needed more than gramophones, contended skeptics, if blind people were to have freedom of choice in their reading material and absolute privacy.

Fraser himself joined the debate after seeing the controversy generated by Copland's polemic. He remained committed to Braille despite having spent the past decade developing an alternative to it. Even so, he read only with difficulty: 'surely very few of us are so good at Braille that it is really no trouble whatever'. ${ }^{97}$ Despite reading Braille every day, Fraser found it difficult to read for longer than an hour without tiring. He added, 'The mind moves so quickly that even the Talking Book is too slow. How much more so Braille' (p. 97).

95 This figure is cited in 'Talking Book or Reading Book? Some Opinions on the Question', 69. Census figures for the blind population in England and Wales from 1851 to 1911 are reprinted in Phillips, The Blind in British Society, 321.

96 Quoted in 'Points from Letters', St. Dunstan's Review, 21.223 (1936), 3.

97 'Talking Book or Reading Book? Sir Ian Fraser's Comments and a Letter from E. Bates', New Beacon (April 15, 1937), 97-8; 97. Hereafter cited parenthetically by page number. 
The central issue here is whether a book's contents remain the same across different media. Book historians acknowledge that the medium influences reception, yet few go so far as to deem one of mode of reading superior to another. ${ }^{98}$ In the New Beacon, a reader named E. Bates made the case for prioritizing the message over the medium: 'Surely the ordinary book, the Braille book, and the gramophone disc are all, in effect, records-the difference between them being simply that their messages are made intelligible to us through different senses-sight, touch, and hearing respectively?' (p. 98) Bates's stance was controversial. True, the words were identical in all three formats. But readers disagreed over whether the message stayed the same after switching from one medium to another. Defenders of reading as a silent activity regard the question of sensory perception as a decisive one.

The narrator's voice was to a large extent responsible for Copland's frustration. He associated books read aloud to him with the 'vocal idiosyncracies' of their readers. ${ }^{99}$ For example, he found it impossible to determine whether one narrator had said 'The cattle began it' or 'The kettle began it' (neither phrase turned out to be correct). ${ }^{100}$ Since the initial experiments in the 1920s, the NIB had recognized problems introduced by the narrator's voice. The NIB's Sound Recording Committee carried out reading trials alongside its technological experiments in order to determine the optimal way of reading. If either theatricality or monotony would be a distraction, the best reader was the least conspicuous one: 'The ideal recorder is one who can sink his own personality and become a part of the mechanism without mechanical effect'. ${ }^{101}$ Fraser reaffirmed a commitment to neutral voices when replying to Copland: 'I do not find the reader intrudes himself between me and the author. I appreciate a good reader, but not for himself. We have aimed, I hope with some success, at choosing readers whose personality is pleasing but not distracting ${ }^{\prime}{ }^{102}$ However, compromise did little to change the minds of those who felt the

98 See D.F. McKenzie's influential formulation of this concept during the Panizzi Lectures in 1985, in Bibliography and the Sociology of Texts (London, 1986), 4. More recent versions can be found in Roger Chartier, The Order of Books: Readers, Authors, and Libraries in Europe between the Fourteenth and Eighteenth Centuries, Lydia G. Cochrane, trans. (Stanford, 1994), 89-91, and N. Katherine Hayles, Writing Machines (Cambridge, 2002), 25.

99 Arthur Copland, 'Talking-Book or Reading-Book', 34.

100 Arthur Copland, 'Talking-Book or Reading-Book', 35.

101 'Report of the Year's Work', Report of the Executive Council of the NIB for the Financial Year Ended 31st March, 1935 (London, 1935), 19-22; 21.

102 'Talking Book or Reading Book? Sir Ian Fraser's Comments and a Letter from E. Bates', 97. 
presence of any reader, no matter how skilled, intruded between themselves and the printed page. ${ }^{103}$

Respondents pointed out the advantages of reading aloud. James Wardle of Greenock dismissed Copland's complaints about thick Scottish accents: 'Certainly if the reading is bad the idiosyncrasy of the reader may enter in, but the readers I have had the pleasure of listening to in Talking Books (and one of them bearing a very Scotch name) have been so perfect as to obliterate all sense of self, and make one unconscious of any third party'. ${ }^{104}$ Others enumerated the benefits of hearing a text. Despite having read four different Braille copies of St. John's Gospel, the Reverend T. Barnard found 'the Talking Book rendering of the old Gospel is a source of unqualified pleasure and profit' (p. 71). There were pleasures as well as perils in hearing books read aloud. Another respondent wrote, 'it should be pointed out that there are many who, when reading for themselves, can make no sense of certain passages (difficult poems, for instance), which are immediately made clear when heard in the voice and interpretation of a capable reader' (p. 68). In such cases, reading aloud made the printed page accessible.

Talking books held further advantages over reading with one's fingers. T. Ap Rhys preferred talking books over Braille because they freed his hands for other activities like smoking: 'Who would choose to sit glued to a book, with smoking out of the question, when he had the alternative of imbibing just the same meaning and being free to smoke, move about the room and, in short, give himself up to full enjoyment?' (p. 71). Women could likewise listen to books while doing housework. 'Group-listening', more commonly associated with radio than with books, was another pastime facilitated by the talking book machine (p. 68). Some blind people listened to recordings with friends and family. ${ }^{105}$ Reading aloud need not be a minority practice. One blind reader's sighted friends preferred hearing V.C. Clinton-Baddeley's recitations on the wireless over reading Dickens and Thackeray for themselves. ${ }^{106}$

Copland remained unconvinced. Debating the quality of narrators, size of the constituency, and machinery's effectiveness, he insisted in a subsequent issue of the New Beacon, sidestepped the principal

\footnotetext{
103 'Talking Book or Reading Book? Sir Ian Fraser's Comments and a Letter from E. Bates', 97.

104 'Talking Book or Reading Book? Some Opinions on the Question', New Beacon (March 1937), 68-71; 70. Hereafter cited parenthetically by page number.

105 'Talking Book or Reading Book? Sir Ian Fraser's Comments and a Letter from E. Bates', 97.

106 'Talking Book or Reading Book? Sir Ian Fraser's Comments and a Letter from E. Bates', 98. On the history of radio recitations, see Robert Giddings and Keith Selby, The Classic Serial on Television and Radio (Basingstoke, 2001).
} 
complaint that the talking book invited inertia. It was suited for entertainment, not instruction. No one had challenged his main point, he continued, that turning blind readers into 'passive buckets, waiting to be pumped into' (a phrase borrowed from Thomas Carlyle) would injure their aspirations towards self-dependence. ${ }^{107}$ Respondents had, in fact, challenged the equation of Braille with self-dependence. Bates, for one, accused Copland of being 'obsessed' with self-dependence at the expense of technological progress. ${ }^{108}$ Nostalgia would not prevent Braille from becoming as obsolete as 'Caxton's primitive wooden printing blocks', charged another reader. ${ }^{109}$ Copland was even accused of an attack on 'civilization itself' ${ }^{110}$ In other words, readers defended the talking book as a step towards the very self-dependence vaunted by Copland.

Forms of mass entertainment including the gramophone, radio, cinema, tabloid press, and paperback book had a profound impact on Britain's cultural traditions in the twentieth century. Widely available in homes by the 1920s and 1930s, the gramophone, in particular, offered audiences unprecedented freedom to hear what they wanted during their leisure time. Freedom of choice became possible for blind people as well. Charities took advantage of advances in sound-recording technology to transform the printed book into a format accessible to people with vision impairments. People who could not read with their eyes or fingers could at least read with their ears. The talking book represented the first practical and affordable means of literacy for the majority of blind people who were unable to read Braille and depended on other people to read to them. The need for prosthetic technology became increasingly evident after the return of blinded soldiers from the First World War who were forced to make the transition from masculine, able-bodied citizens into objects of charity, dependent on others. The plight of these veterans prompted St. Dunstan's and the NIB to test various mechanical reading devices throughout the 1920s and early 1930s that would ultimately benefit all blind people. Talking books made it possible for thousands of blind people to read for themselves. Testimonials show that readers responded to talking books both as a revival of their former reading practices and as a new form of reading distinguished by sound effects. They held forth the prospect of remedying problems affecting the blind community such as boredom,

\footnotetext{
107 Arthur Copland, 'Talking-Book or Reading-Book? A Reply', New Beacon (May 1937), 132-3; 133.

108 Copland, 'Talking-Book or Reading-Book? A Reply', 98.

109 'Talking Book or Reading Book? Some Opinions on the Question', 69.

110 'Talking Book or Reading Book? Some Opinions on the Question', 71.
} 
dependency, depression, social isolation, and a lack of privacy. The machinery had therapeutic value in particular for traumatized veterans.

The convergence of books, media, and disability in the War's aftermath raised a vexing set of questions that have yet to be resolved about the nature of reading. The most problematic of these questions concern the legitimacy of alternative forms of literacy, rivalry between print media and new media, and definition of self-sufficiency. Similar questions persist to this day when discussing the printed book in the context of an increasingly multimedia environment. Yet, these questions take on a different hue when considered in relation to a group of disabled readers who would not otherwise have access to books at all. The Talking Book Service ensured that blind soldiers and civilians could read even when other people were not available to read to them. In doing so, it confirmed that books could take many forms-even if the appropriateness of these various forms was matter for intense debate among both blind and sighted readers.

The Talking Book Service made substantial progress after its modest origins supplying reading material to wounded soldiers. At the end of the Second World War, the Service had 1,700 members and 500 books in its library. ${ }^{111}$ It had over 40,000 members and a library of over 20,000 titles as of January 2005. The Service now sends out between 8-10,000 books per day. This is a dramatic improvement over the situation that faced soldiers coming back from the First World War. Britain's blind and partially sighted people face many difficulties today. The Talking Book Service is part of an ongoing campaign to ensure that access to books is no longer one of them. In 2012, the same year that the RNIB celebrated the Service's seventy-fifth anniversary, it estimated that only 7 per cent of all titles were available in accessible formats including large print, unabridged audio, and Braille. ${ }^{112}$ The World Blind Union described the lack of accessible formats for blind people as a book famine'. ${ }^{113}$ The Talking Book Service was hailed by its founders as a solution to the problem of accessibility. Instead, it has brought to public attention the magnitude of the challenges involved in adapting new media to the needs of people with disabilities.

\footnotetext{
111 'Talking Books', NIB Report for 1945-1946 (London, 1946), 18-19; 18.

112 Sight Loss UK 2012: The Latest Evidence (London, 2012), 15. <http:/ / www.rnib.org.uk/ aboutus/Research/reports/2012/Sight_loss_uk_2012.pdf $>$. The report is based on the findings in Helen Greenwood, Sonya White, and Claire Creaser, 'Availability of Accessible Publications: 2011 Update', Report to RNIB, 24 October 2011, <http://www.rnib.org.uk/ aboutus/Research/reports/reading/Pages/accessible_publishing_research.aspx>.

113 'Committee on the Rights of Persons with Disabilities Day of General Discussion on "Accessibility", paper presented by the World Blind Union at the Convention on the Rights of Persons with Disabilities, 7 October 2010, 1. <http://www.ohchr.org/EN/ HRBodies/CRPD/Pages/DGD7102010.aspx>.
} 